\title{
Mechanical properties and simulation of finite element firmness in Carica papaya L. Tainung F1 cultivated on the high Sinu (Cordoba-Colombia)
}

\section{Propiedades mecánicas y simulación de la firmeza con elementos finitos en (Carica papaya L) Tainung F1 cultivada en el alto Sinú (Córdoba-Colombia)}
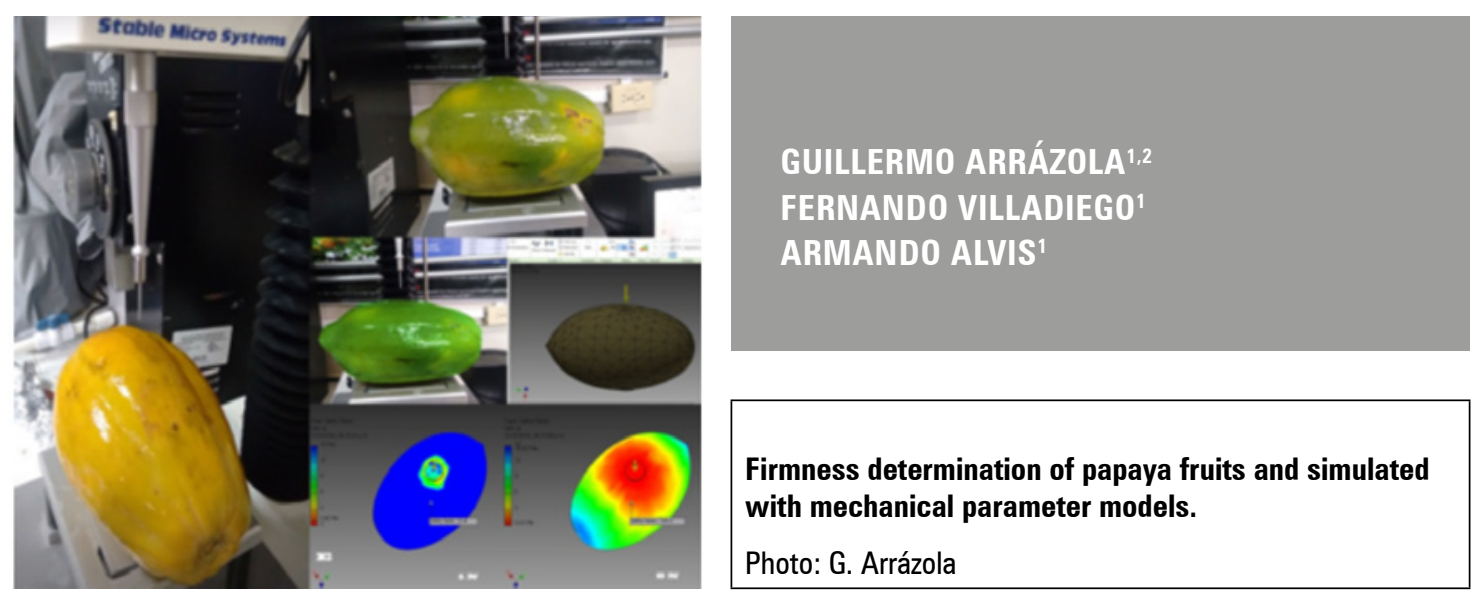

\section{ABSTRACT}

The objective of this research was to evaluate Tainung F1 papaya fruits in five degrees of ripeness, analyzing mechanical resistance and modeling behavior with finite element analysis to generate important postharvest and transport management data. Tainung F1 papaya fruits were evaluated in five degrees of ripeness by analyzing their mechanical strength. Firmness was determined by applying a uniaxial penetration test and mechanical properties with an axial compression test. The firmness modeling and simulation was done with Autodesk inventor professional 15.0 (ANSYS® Technology). The deformability modulus decreased with the increase in the degree of ripeness, from $1.81 \mathrm{MPa}$ to $0.52 \mathrm{MPa}$ for degree of ripeness 1 to degree of ripeness 5 . The yield strength varied from $0.0073 \mathrm{MPa}$ to $0.00239 \mathrm{MPa}$ for the same range. The finite element simulation of the fruit firmness showed a negative correlation with the degree of ripeness.

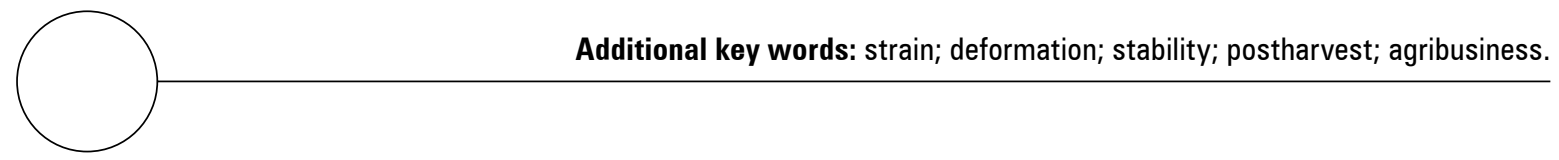

\footnotetext{
University of Cordoba, Faculty of Engineering. Vegetable Processes and Agroindustry Research Group, Berastegui (Colombia). ORCID Arrázola, G.: 0000-0001-6878-0806; ORCID Villadiego, F.: 0000-0003-0495-6942; ORCID Alvis, A.: $0000-0002-5638-271 \mathrm{X}$

2 Corresponding author: gsarrazola@correo.unicordoba.edu.co
} 


\section{RESUMEN}

El objetivo de esta investigación fue evaluar el fruto de papaya Tainung F1 en cinco grados de madurez, analizando su resistencia mecánica y modelando su comportamiento a través del análisis de elementos finitos para brindar importantes datos de manejo postcosecha y de transporte. Los frutos de papaya Tainung F1 se evaluaron en cinco grados de madurez analizando su resistencia mecánica. La firmeza se determinó aplicando una prueba de penetración uniaxial y las propiedades mecánicas mediante una prueba de compresión axial. El modelado y simulación de firmeza fue realizado por el software Autodesk Inventor Professional 15.0 (Tecnología ANSYS®). El módulo de deformabilidad disminuyó con el aumento del grado de madurez de $1.81 \mathrm{MPa}$ a $0.52 \mathrm{MPa}$ entre el grado de madurez 1 y el grado de madurez 5. El límite elástico osciló entre $0.0073 \mathrm{MPa}$ y $0.00239 \mathrm{MPa}$ respectivamente en la maduración 5. La simulación de elementos finitos de la firmeza del fruto mostró una correlación negativa con el grado de maduración.

Palabras clave adicionales: presión; deformación; estabilidad; poscosecha; agroindustria.

Received: 28-03-2020 Accepted: 08-11-2020 Published: 26-01-2021

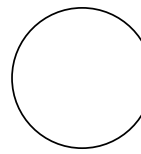

Papaya's center of origin is in the lowlands of the tropical Americas, from southeastern Mexico to Costa Rica, although it is currently found in all tropical regions of the world. According to Garcia (2010), the papaya fruit can be cylindrical, elongated, pearshaped, oval or round, characteristic of the Carica genus. All Carica species are from the tropical Americas and have been used for consumption because of their various health properties. Currently, these characteristics are not relevant for commercialization because organoleptic characteristics prevail (Jimenez, 2002).

The Tainung F1 papaya fruits are a hybrid developed for the first time in Taiwan. The plants have three types: females, males and hermaphrodites (Gil and Miranda, 2005). In Colombia, it is commercialized as the F1 commercial hybrid seed. The plants have heights of 2 to $2.8 \mathrm{~m}$, a factor that predetermines crop productivity. The fruits have an elongated shape when they come from hermaphroditic and an elliptical shape when they come from female plants (Alonso et al., 2009). The measurement of elastic properties in fruits and vegetables can be estimated with a simple penetration test coupled to a texturometer, obtaining force versus distance curves that are needed for the calculation of mechanical parameters such as force or penetration effort. Uniaxial compression tests have also been widely used, which provide stress versus strain data and the maximum breaking force for calculating the modulus of deformability and the rupture energy (Alvis et al., 2009).

\section{INTRODUCTION}

One of the important measurements in the textural characterization of fruits is firmness, which measures the resistance to mechanical damage during harvest and transport (Ciro et al., 2005; Rangel-Montes de Oca et al., 2018; Sanchez et al., 2020). The sum of the elastic and plastic deformations of a certain point in the force-deformation curve is used to calculate the unit deformation in the expression of the module. Firmness is the consistency of fruits and is used to determine the optimal harvest timing (Barreiro and Ruiz, 1996). Each material is characterized by a deformation curve in response to variable forces applied to its surface (Zapata et al., 2010).

Stress, defined as a force on a unit of area and generally expressed in $\mathrm{Pa}\left(\mathrm{N} \mathrm{m}^{-2}\right)$, can be produced by tension, compression or cuts, while deformation, a dimensionless measurement, changes the original length of the material (Ramírez, 2006; Alvis et al., 2009). The software Autodesk Inventor Professional 15.0 Technology ANSYS® submits models of mechanical parameters to studies with computer-aided engineering, when performing a stress analysis (Rojas et al., 2013). This software is parametric type and creates models of solids supported in the constructive geometry (Bonifácio et al., 2019).

The ANSYS module assembles the design-manufacture-production process. Graphic system techniques are numerous and vary according to the purpose of the measurements and needs (Sanz and Lafargue, 
2002). The objective of this research was to calculate the mechanical parameters of Tainung F1 papaya and simulate firmness in different ripeness degrees.

\section{MATERIALS AND METHODS}

The determinations were made with Tainung F1 papaya fruits harvested by the Asociación Agroecologica de Productores y Comercializadores de Papaya del Alto Sinu (APPALSI) in Tierralta, on the upper Sinu River, in the Department of Cordoba, Colombia, and kept at an average temperature of $27.4^{\circ} \mathrm{C}$, the ambient temperature, without irrigation. The analysis of the results obtained in the mechanical characterization was adjusted to an experiment design based on the recommendations of studies carried out by Santamaria et al. (2009), which was completely randomized with 10 replicates for each degree of ripeness.

In the penetration test, a $2 \mathrm{~mm}$ diameter stainless steel cylindrical probe attached to a TA-XTPlus model texturometer (Stable Micro Systems, Surrey, UK) was used to calculate the "maximum penetration effort". The trials were performed on the entire fruit with peel. In all cases, the test was adjusted to a deformation rate of $5 \mathrm{~cm} \mathrm{~min}{ }^{-1}$ at room temperature $\left(25^{\circ} \mathrm{C}\right)$. The compression test was performed unaxially on fruit samples cut into cubes with a 2 $\mathrm{cm}$ edge. A $75 \mathrm{~mm}$ compression plate was used, and the compression distance was $5 \mathrm{~mm}$ with a speed of $10 \mathrm{~mm} \mathrm{~s}^{-1}$.

The fruit firmness simulation was performed with Autodesk Inventor Professional (San Rafael, CA) and ANSYS 15.0 (ANSYS Inc, Canonsburg, PA), which aided the finite element modeling and simulation (Moaveni, 1999). This software submits mechanical parameter models to computer-aided engineering studies when performing a stress analysis (Rojas et al., 2013). This software is parametric and generates solid models supported in the constructive geometry.

For the calculation of density, the volume of the fruit was determined with Archimedes principle. The Poisson coefficient was determined for each degree of ripeness; a 49 Newton load cell was used, with an operating speed of $2 \mathrm{~mm} \mathrm{~s}^{-1}$ and $75 \mathrm{~mm}$ compression plate. For the test, the fruits were supported on the peduncle, and the axis of application of the force corresponded to the longitudinal axis of the fruits. The compression distance was set at $5 \mathrm{~mm}$. The Poisson coefficient was calculated with equation 1 :

$$
\mu=\frac{\frac{\Delta D}{D}}{\frac{\Delta L}{L}}
$$

where $\mu$ was the Poisson coefficient (adimensional), $\Delta D$ was the lateral deformation $(\mathrm{mm}), D$ was the initial cross length $(\mathrm{mm}), \Delta L$ was the longitudinal deformation $(\mathrm{mm})$ and $L$ was the longitudinal dimension $(\mathrm{mm})$.

The data were analyzed with analysis of variance (ANOVA), $P<0.05$. The means were compared with Tukey's multiple range tests $(P \leq 0.05)$ for the mechanical properties and with the t-student test to compare the simulation data with the experiment data. All statistical data were analyzed with STATGRAPHICS Centurion XVI v. 16.1.1 and IBM SPSS Statistics v. 23

\section{RESULTS AND DISCUSSION}

\section{Mechanical parameters for the firmness and penetration strength}

The compression deformability module analysis was determined from the stress curve $(\mathrm{MPa})$ vs. relative deformation (\%) (Fig. 1). An average value of $1.81 \pm 0.12 \mathrm{MPa}$ was obtained for degree of ripeness 1 , which decreased to $0.52 \pm 0.015 \mathrm{MPa}$ for degree of ripeness 5 .

As stated by Mohsenin (1970), deformation stress curves provide very specific mechanical indexes for food, such as the elastic limit, the bioyeld point, the plastic range and the point of rupture. Figure 1 shows that, for papaya Tainung F1, there was no bioyeld point in the fruits subjected to axial compression in ripening degrees 1 and 2, while the bioyeld was remarkable in ripening degrees 3,4 and 5 . This characteristic is associated with the absence of cellular internal rupture within the range of deformation, giving way to the rupture of the sample when there is bioyeld (Mohsenin, 1972).

In the maturation stage, the action of enzymes degrades the cell wall of plants by breaking pectin 


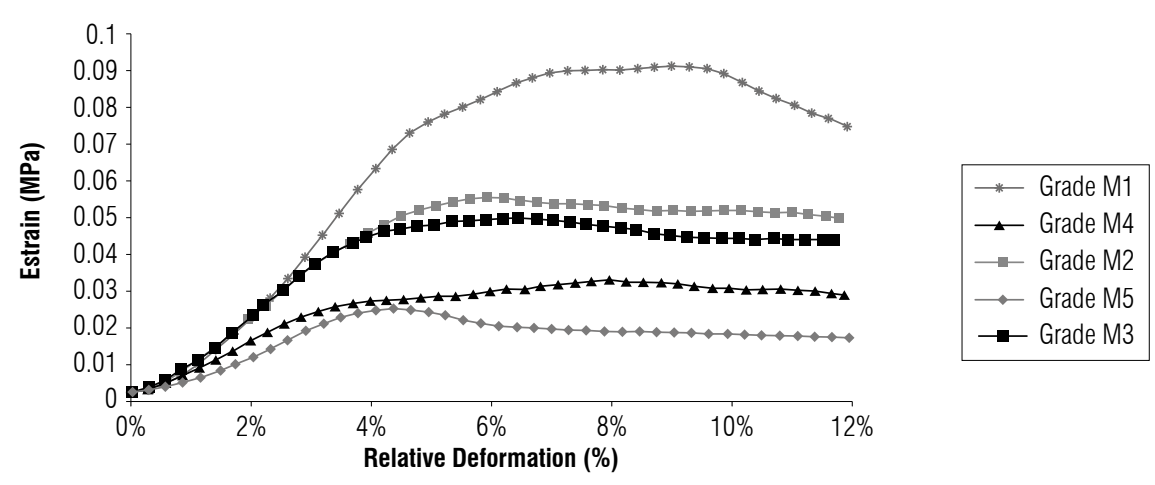

Figure 1. Stress curve deformation in Tainung F1 papaya fruits.

chains. These processes can decrease the modulus of deformability by $50 \%$ as maturity advances, as compared to maturity degrees zero and one (Errington $e t$ al., 1997; Wang, 2006; Namdari et al., 2020).

The results obtained from the stress strain curves are shown in table 1. Poisson's coefficient increases with the degree of maturity and presented significant differences according to the Tukey test $(P \leq 0.05)$. Table 2 shows the comparison between the strengths obtained experimentally and those obtained by simulation. The t-student test revealed that there were no significant differences between both measurements.
For the other mechanical parameters, such as density, the values increased with the degree of ripeness and presented a slight drop in the ripenness levels 4 and 5. There was not a significant difference between the five degrees of ripeness. The behavior of density has been described by Villamizar (2001) as being the result of the flow of gaseous components of fruits from internal spaces towards the outside as ripening progresses. The decrease in density in advanced degrees of ripeness could be related to respiration, water loss through transpiration and air inside the fruit (Osterloh et al., 1996; Wills et al., 1998; Pinzón et al., 2007; Uba et al., 2020).

Table 1. Mechanical properties of Tainung F1 papaya fruits for five degrees of ripeness.

\begin{tabular}{|c|c|c|c|c|}
\hline Degrees of ripeness & Density $\left(\mathrm{kg} \mathrm{m}^{-3}\right)$ & Poisson coefficient & Deformability module (MPa) & Elasticity limit (MPa) \\
\hline 1 & $0.90 \pm 0.001 \mathrm{a}$ & $0.46 \pm 0.13 \mathrm{e}$ & $1.81 \pm 0.12 \mathrm{a}$ & $7.31 \cdot 10^{-2} \pm 0.002 \mathrm{a}$ \\
\hline 2 & $0.94 \pm 0.007 \mathrm{a}$ & $0.47 \pm 0.22 \mathrm{~d}$ & $0.85 \pm 0.015 \mathrm{~b}$ & $5.06 \cdot 10^{-2} \pm 0.002 \mathrm{~b}$ \\
\hline 3 & $0.95 \pm 0.006 \mathrm{a}$ & $0.69 \pm 0.19 \mathrm{c}$ & $0.70 \pm 0.013 \mathrm{bc}$ & $4.30 \cdot 10^{-2} \pm 0.003 \mathrm{c}$ \\
\hline 4 & $0.94 \pm 0.002 \mathrm{a}$ & $0.78 \pm 0.11 \mathrm{~b}$ & $0.68 \pm 0.012 \mathrm{~d}$ & $2.46 \cdot 10^{-2} \pm 0.002 \mathrm{~d}$ \\
\hline 5 & $0.94 \pm 0.003 \mathrm{a}$ & $0.94 \pm 0.008 \mathrm{a}$ & $0.52 \pm 0.015 \mathrm{~d}$ & $2.39 \cdot 10^{-2} \pm 0.002 \mathrm{~d}$ \\
\hline
\end{tabular}

Means indicate significant differences according to the Tukey test $(P \leq 0.05)$.

Table 2. Comparison between the firmness strength obtained experimentally and that obtained by simulation in Tainung F1 papaya.

\begin{tabular}{|c|c|c|c|c|}
\hline Ripeness degree & Simulated strength (N) & Experimental strength (N) & Safety factor & \%Error \\
\hline 1 & 65 & 58.65 & 0.25 & 10.83 \\
\hline 2 & 40 & 41.84 & 0.42 & 4.40 \\
\hline 3 & 25 & 33.34 & 0.93 & 25.01 \\
\hline 4 & 22 & 21.45 & 0.84 & 2.50 \\
\hline 5 & 18 & 19.7 & 0.86 & 8.63 \\
\hline
\end{tabular}

$95 \%$ confidence intervals, standard deviation of simulated firmness: 16.5523 and 29.4902; standard deviation of peel: 11.4193 and 20.345 ; range of variances: 0.925876 to 4.76791 ; F-test for comparing standard deviations: $\mathrm{F}=2.10107, P=0.0750865$. 
Poisson's coefficient expresses an increase with the degree of ripeness and presents significant differences according to the Tukey test $(P \leq 0.05)$. Said behavior reflects a greater lateral deformation with respect to longitudinal deformation during the compression of fruits. In behavioral studies on fruits, such as mango (Mangifera indica), Poisson's values have been reported as $0.54,0.66$ and 0.94 , respectively, for green, medium-ripe and mature fruits (Mayans et al., 2015).

The axial compression test performed on the Tainung F1 papaya samples provided the maximum strength data shown in table 3 .

Table 3. Maximum strength of uniaxial compression in Tainung papaya fruits F1.

\begin{tabular}{|c|c|}
\hline Ripeness grade & Breaking point (N) \\
\hline 1 & $1005.56 \pm 0.29 \mathrm{a}$ \\
\hline 2 & $475.00 \pm 0.42 \mathrm{~b}$ \\
\hline 3 & $342.81 \pm 0.37 \mathrm{c}$ \\
\hline 4 & $168.01 \pm 0.85 \mathrm{~d}$ \\
\hline 5 & $126.98 \pm 0.23 \mathrm{e}$ \\
\hline
\end{tabular}

Means with different letters indicate significant differences according to the Tukey test $(P<0.05)$.

The analysis of variance of the mechanical parameters, deformability modulus and limit of elasticity submitted to the Tukey test $(P \leq 0.05)$ showed significant differences between the modules measured for the initial degrees of ripening and the consumption ripeness stage, whereas ripeness grades 4 and 5 did not show statistical differences. The modulus of deformability, calculated as the slope of the linear part of the stress vs. strain curve, showed differences between the degrees of maturity and was lower for grades 4 and 5 . A mean value of $1.81 \pm 0.12 \mathrm{MPa}$ was obtained in the degree of maturity (1) and decreased to $0.52 \pm 0.015 \mathrm{MPa}$ in degree of ripeness 5 . This effect is attributable to the loss of firmness in fruits during the maturation process (Ciro et al., 2005).

The modulus of deformability is suggested as a measure of firmness in fruits, and the limit of elasticity elucidates the maximum load that a fruit can withstand during storage under the action of static charges (Chen et al., 1987). In other vegetables, such as yams, modulus of deformability values of $1.7 \mathrm{MPa}$ are indicated on average, while the sweet potato has values of 4.39 MPa (Alvis et al., 2015). Keitt variety mangoes have deformability modules of $2.065 \mathrm{MPa}$ at physiological maturity (green) and 1.31 $\mathrm{MPa}$ with consumption ripeness. Fruits with a higher fiber content have greater resistance and higher deformability modulus values (Negrín et al., 2013). Guava fruits (Psidium guajava) have values of $3.51 \mathrm{MPa}$ when green fruit and $1.22 \mathrm{MPa}$ with consumption ripeness, with reports of $0.91 \mathrm{MPa}$ for ripe fruits (Fernández et al., 2013). Babarinsa and Ige (2014) observed deformability modules from 1.14 to $1.87 \mathrm{MPa}$ in their studies on the tomato Roma variety. The yield limit for the Tainung F1 papaya ranged from $7.31 \cdot 10^{-2} \pm 0.0021$ $\mathrm{MPa}$ at ripeness level 1 to $2.39 \cdot 10^{-2} \pm 0.0022 \mathrm{MPa}$. This parameter has been reported in fruits, such as guava, with values of $0.22 \mathrm{MPa}$ in physiological ripening, along with values of $0.018 \mathrm{MPa}$ in soursop in green fruits and $0.0013 \mathrm{MPa}$ for fruits with consumption ripeness (Marquez, 2009; Yam et al., 2009; Kabas et al., 2015).

The axial compression test in table 3 showed that the fruits had a greater sensitivity to the rupture of tissue in the mesocarp and exocarp in the equatorial zone because of the effect of tension during compression.

In studies carried out on mechanical resistance to rupture in papaya variety Maradol Red, rupture point values of approximately $90 \mathrm{~N}$ were reached for the consumption ripeness stage and $250 \mathrm{~N}$ in other cultivars of the same variety. Physiological ripening (degrees of ripeness 0.1 and 2) can have maximum strength of rupture values of $2000 \mathrm{~N}$ and $2,500 \mathrm{~N}$, as reported by Vázquez et al. (2003, 2013).

Studies conducted by Villaseñor et al. (2006) have shown that low axial compression on less mature fruits in the vertical position can register higher compression loads when reaching the elastic limit and breaking point. In comparison with the data obtained in this study, melons (Cucumis melo) present average values of $411 \mathrm{~N}$ at commercial maturity and $1950 \mathrm{~N}$ in fruits with degree 1 ripeness.

The physiological behavior of compressed fruits is not different from the behavior of intact fruits, provided that the compression load does not exceed the limit of elasticity of the fruit.

The results of the present study indicate that the loading position of the Tainung F1 papaya had a significant effect on the mechanical response of the product, with more resistance to uniaxial compression than to unidirectional compression, which can originate with the structural heterogeneity of the 


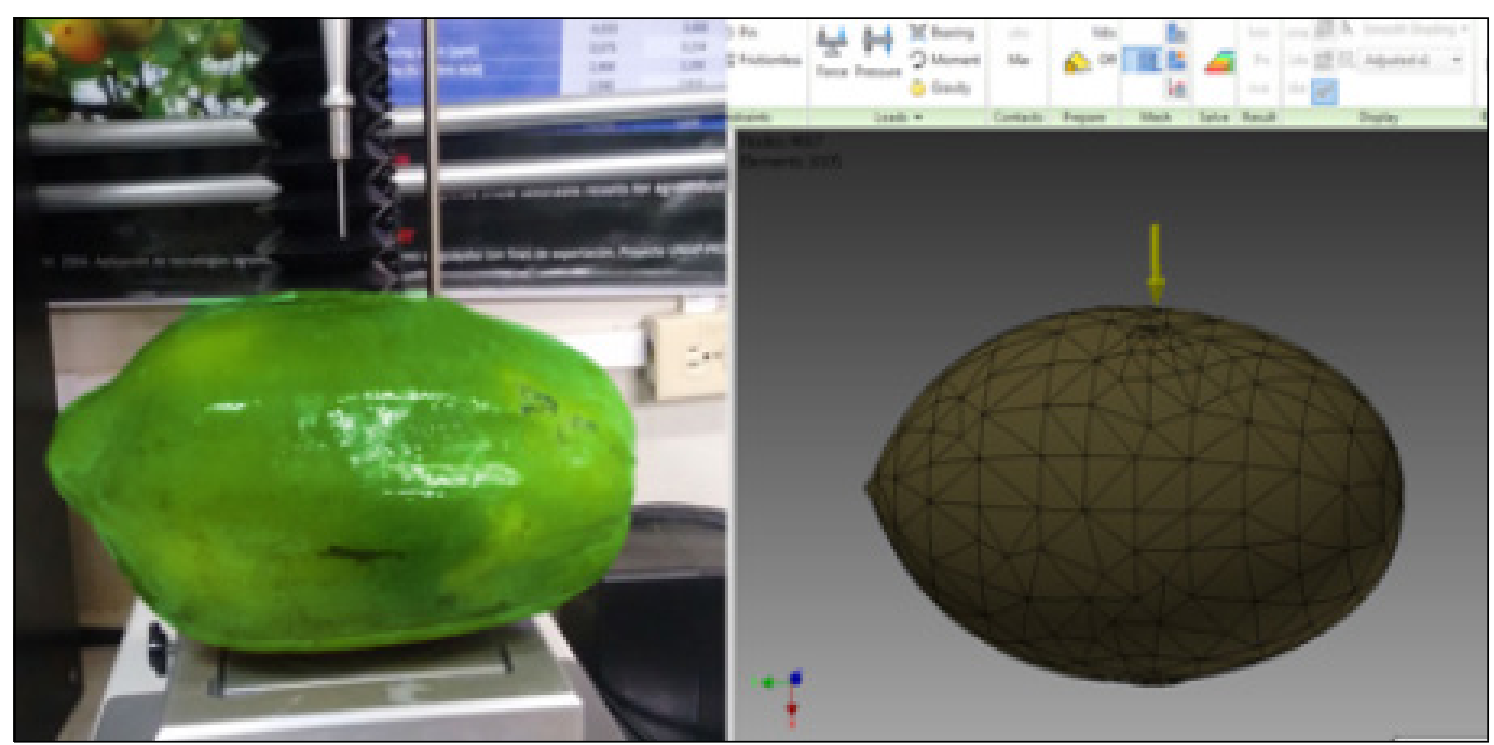

Figure 2. Experiment test of firmness and simulated firmness test with the entanglement of the solid with finite elements for the Tainung F1 papaya fruits.

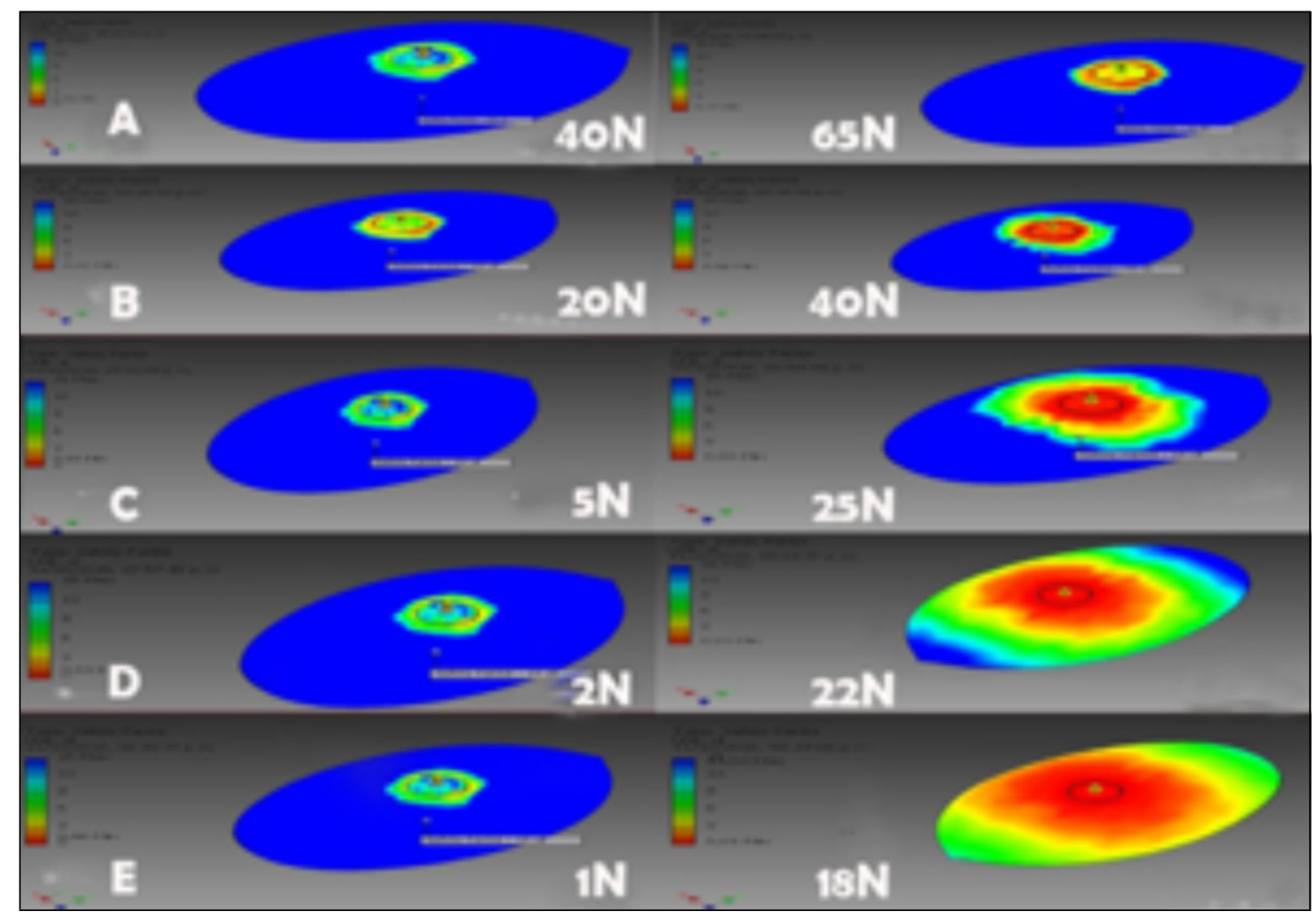

Figure 3. Results of the firmness simulation for Tainung F1 papaya fruits in ripeness stages 1 (A), 2 (B) and 3 (C), 4 (D) and 5 (E). 
pulp-skin with materials and nanotechnology (Stroshine, 1999; Zhang et al., 2005; Chandran, 2020).

Figure 2 shows the mesh of the solid when applying finite elements for the monitoring of the firmness by simulation; a comparison between the current test and the simulated test is included.

Figure 3 shows the results obtained with the simulated tests when using the software for a numerical analysis with finite elements by means of a homogeneous-continuous-isotropic-linear-elastic model.

The results of the simulation (Fig. 3), the application of a smaller force and the force that ruptured the fruit because of a loss of firmness in the test are shown. The darker areas, which appear red, determined the area that was most affected during the test and the rupture of the plant tissue.

The simulation of finite elements in other fruits, such as guava, have reported values of 3 to $9 \%$ displacement during simulated compression tests and compression zone for the greater effort as in the Tainung F1 papaya, which extends from radial shape (Fernández et al., 2014). The simulation clearly showed the zones of greatest tension in the fruits subjected to a load. The results in table 2 compare the strengths obtained experimentally and those obtained by simulation. The t-student test showed that there were no significant differences between the measurements.

When observing the adjustment error between the measurements, the simulation was adjusted more for degrees of ripeness 2, 4 and 5. Zeebroeck et al. (2006) reported simulated impact loads on apples with an error of $5 \%$ with respect to experiment impact loads. Similarly, Cherng et al. (2005) obtained errors of $6 \%$ in a study on firmness in ellipsoidal fruits. According to Bourne (2002), biological materials have three types of fractures: a simple type that occurs when the body separates into two or more pieces, a fragile type that occurs when there is low absorption of energy before deformation, and a ductile type that occurs when there is high absorption of energy in the material before it ruptures.

During this process, first an internal fracture occurs while the outside of the structure remains instance. Finally, a rupture with physical disintegration occurs (Pollak and Peleg, 1980). The safety factor shown in table 2 expresses the applied stress on the limit stress of the material under test for degrees of maturity
3,4 and 5 . This value is closer to unity, a fact that represents the highest probability of failure of the structure in fruits subjected to an external force, as expressed by Salazar (2007). Safety is related to the probability of failure of the structure; the lower this probability is, the lower the safety factor.

\section{CONCLUSIONS}

The results obtained in this study could be used to develop devices for harvesting and to design technologies for better technical and energy performance. The mechanical response of the Tainung F1 papaya fruits was affected by ripening. There was greater resistance with the shorter post-harvest time. The modulus of deformability and the elastic limit of the Tainung F1 papaya decreased as the ripening progressed, which constitutes fruit softening. This loss of rigidity is one of the most obvious changes during the maturation process in viscoelastic materials. For the Tainung F1 papaya, there was no bioyield point in the fruits subjected to axial compression in degrees of ripeness 1 and 2 , but while the bioyeld was remarkable in degrees of ripening 3,4 and 5 . This result demonstrated that fruit transport is safer in degrees of ripeness 1 and 2 , where there is greater internal resistance in the equatorial tissue. Numerical techniques, such as the finite element method in ANSYS $₫$, can reduce experiments that determine static charge damage in Tainung F1 papaya fruits.

\section{ACKNOWLEDGMENT}

The authors thank the University of Córdoba, the Food Engineering Program, the Agroecological Association of Producers of Papaya del Alto Sinu (Cordoba-Colombia) APPALSI, and Sinufoods S.A.S. Colombia.

Conflict of interests: The manuscript was prepared and reviewed with the participation of the authors, who declare that there exists no conflict of interest that puts at risk the validity of the presented results.

\section{BIBLIOGRAPHIC REFERENCES}

Alonso, M., Y. Tornet, R. Ramos, and E. Farres. 2009. Evaluación de dos híbridos de papaya introducidos en cuba. Agron. Costarric. 33(2), 267-74. 
Alvis, A., A. González, and G. Arrazola. 2015. Efecto del recubrimiento comestible en las propiedades de trozos de batata (Ipomoea batatas Lam) fritos por inmersión. Parte 2: Propiedades termofísicas y de transporte. Inf. Tecnol. 26(1), 103-116. Doi: 10.4067/ S0718-07642015000100012

Alvis, A., M. Páez, and J. Lafont. 2009. Propiedades mecánicas y viscoelásticas del ñame (Dioscórea alata). Inf. Tecnol. 20(5), 75-81. Doi: 10.4067/S0718-07642009000500010

Babarinsa, F.A. and M.T. Ige. 2014. Strength parameters of packaged Roma tomatoes at break point under compressive loading. pp. 31-35. In: Proc. $5^{\text {th }}$ International Conference on Food Engineering and Biotechnology. Vol. 65. IACSIT Press, Singapore.

Barreiro, P. and M. Ruiz. 1996. Propiedades mecánicas y calidad de frutos definiciones y medidas instrumentales. Frutic. Prof. 77, 48-51

Bonifácio, A., J. Mendes, M. Faragea, S. Barbosa, C. Barbosa, and A. Beaucour. 2019. Application of support vector machine and finite element method to predict the mechanical properties of concrete. Lat. Am. J. Solids struct. 16(7), e205. Doi: 10.1590/1679-78255297

Bourne, M. 2002. Food texture and viscosity. $2^{\text {nd }}$ ed. Academic Press, New York, NY. Doi: 10.1016/ B978-012119062-0/50001-2

Ciro, H., M. Montoya, and L. Milán. 2005. Caracterización de propiedades mecánicas del banano (Cavendish valery). Rev. Fac. Nac. Agron. Medellín 58(2), 2975-88.

Chandran, R. 2020. Finite element analysis in nanotechnology research. In: Finite element methods and their applications. IntechOpen, New Delhi.

Chen, P., M. Ruiz, F. Lu, and A.A. Kader. 1987. Study of impact and compression damage on Asian pears. Trans. ASAE 30(4), 1193-1197. Doi: 10.13031/2013.30543

Cherng, A., F. Ouyang, L. Blot, and R. Zwiggelaar. 2005. An estimation of firmness for solid ellipsoidal fruits. Biosyst. Eng. 91(2), 257-259. Doi: 10.1016/j. biosystemseng.2005.02.011

Errington, N., J. Mitchell, and J. Tucker. 1997. Changes in the force relaxation and compression responses of tomatoes during ripening: The effect of continual testing and polygalacturonase activity. Post-harvest Biol. Technol. 11, 141-147. Doi: 10.1016/S0925-5214(97)00020-3

Fernández, D., A. Ocampo, A. García, and A. Hernández. 2013. Análisis numérico de la resistencia mecánica del fruto de la guayaba en diversos estados de maduración. Científica 17(4), 171-80.

Fernández, D., A. Ocampo, A. García, and A. Hernández. 2014. Evaluación numérico-experimental de los esfuerzos principales en la corteza del fruto de la guayaba (Psidium guajava $\mathrm{L}$ ) variedad enana roja. Rev. Cie. Téc. Agr. 23(1), 60-67.

García, M. 2010. Guía técnica del cultivo de papaya. In: http://www.centa.gob.sv/docs/guias/frutales/
GUIA\%20CULTIVO\%20PAPAYA.pdf; consulted: Octuber, 2020.

Gil, A. and D. Miranda. 2005. Morfología de la flor y de la semilla de papaya (Carica papaya L.) variedad Maradol e híbrido Tainung-1. Agron. Colomb. 23(2), 217-22.

Jiménez, J. 2002. El cultivo de la papaya Hawaiana. Editorial EARTH, San Jose. pp. 20-30.

Kabaş, Ö. and V. Vladut. 2015. Determination of drop test behavior of a sample peach using finite element method. Int. J. Food Prop. 18(11), 2584-2592. Doi: 10.1080/10942912.2014.994069

Márquez, C. 2009. Caracterización fisiológica, físico-química, geológica, nutraceúticas, estructural y sensorial de la guanábana (Annona muricata L. cv. Elita). PhD thesis. Faculty of Agricultural Sciences, Universidad Nacional de Colombia, Medellin, Colombia.

Mayans, P., G. López, E. Romanchik, and L. Pérez. 2015. Propiedades elásticas del sistema fruto-pedicelo del mango relacionadas con la cosecha por vibración. Rev. Mex. Cienc. Agríc. 6(8), 1781- 1790. Doi: 10.29312/ remexca.v6i1.747

Moaveni, S. 1999. Finite element analysis thory and application with ANSYS. Prentice-Hall, Upper Saddle River, NJ.

Mohsenin, N. 1970. Physical properties of plant and animal materials. Vol. I: Structure, physical caracteristics and mechanical. Gordon and Breach Science Publishers, New York, NY.

Mohsenin, N. 1972. Mechanical properties of fruits and vegetables. Review of a decade of research aplications and future needs. Trans. ASAE 10, 1064-1070. Doi: 10.13031/2013.38072

Namdari, B., G. Hossein, and M. Majid, 2020. Ripeness detection of orange fruit using experimental and finite element modal analysis. Sci. Hortic. 261, 108958. Doi: 10.1016/j.scienta.2019.108958

Negrín, L., R. Barros, A. Da Silva, A. Figueiredo, and N. Cárdenas. 2013. Comportamiento mecánico de dos variedades de mango (Mangifera indica) bajo compresión axial. Rev. Cienc. Téc. Agropec. 22(2), 11-15.

Osterloh, A., G. Ebert, W.H. Held, H. Schulz, and E. Urban. 1996. Lagerung von Obst und Südfrüchten. Verlag U1mer, Stuttgart, Germany.

Pinzón, I., G. Fischer, and G. Corredor. 2007. Determinación de los estados de madurez del fruto de la gulupa (Passiflora edulis Sims). Agron. Colomb. 25(1), 83-95.

Pollak, N. and M. Peleg. 1980. Early indications of failure in large compressive deformation of solids foods. J. Food Sci. 45(4), 825-835. Doi: 10.1111/j.1365-2621.1980. tb07459.x

Ramírez, J. 2006. Introducción a la reología de los alimentos. ReCiTelA 6(1), 15-25.

Rangel-Montes de Oca, L., L.L. Monzón-Monraba, J. Garcia-Coronado, and A. García-Pereira. 2018. 
Mathematical techniques to infer post-harvest changes in the properties of agricultural products. Rev. Cie. Téc. Agr. 27(4).

Rojas, J., J. Montalvo, and M. Castro. 2013. Modelado tridimensional y análisis funcional de una cabria para la extracción del mineral. Dyna 80(181), 118-25.

Salazar, E. 2007. Resistencia de materiales básica para estudiantes de ingeniería. Universidad Nacional de Colombia, Manizales, Colombia.

Sanchez, N., G.F. Gutiérrez-López, and G. Caez-Ramírez. 2020. Correlation among PME activity, viscoelastic, and structural parameters for Carica papaya edible tissue along ripening. J. Food Sci. 85(2), 1805-1814. Doi: 10.1111/1750-3841.15130

Santamaría, F.B., E. Sauri, F. Espadas, R. Díaz, A. Larqué, and J.M. Santamaría. 2009. Postharvest ripening and maturity indices for maradol papaya. Interciencia 34(8), 583-588

Sanz, F. and J. Lafargue. 2002. Diseño industrial y desarrollo del producto. Thomson, Madrid.

Stroshine, R. 1999. Physical properties of agricultural materials and food products. Department of Agricultural and Biological Engineering, Purdue University, West Lafayette, IN.

Uba, F., E.O. Esandoh, D. Zogho, and E.G. Anokye. 2020. Physical and mechanical properties of locally cultivated tomatoes in Sunyani, Ghana. Sci. Afr. 10, e00616. Doi: 10.1016/j.sciaf.2020.e00616

Vázquez, G., F. Chávez, F. Ariza, K. Yahia, Z. Salazar, V. Saucedo, and L. Colinas. 2003. Propiedades mecánicas de frutos de papaya Maradol roja bajo comprensión estática. Rev. Chapingo Ser. Hortic. 9(2), 341-351. Doi: 10.5154/r.rchsh.2000.12.088

Vázquez, G., E. Mata, H. Vázquez, R. Ariza, B. Santamaría, and I. Alia. 2013. Comportamiento mecánico de frutos de papaya bajo compresión axial. Rev. Mex. Cienc. Agríc. 4(8), 1223-1235. Doi: 10.29312/remexca. v4i8.1135
Villamizar, F. 2001. Manejo tecnológico postcosecha de frutas y hortalizas: Aspectos teóricos. Facultad de Ingeniería, Universidad Nacional de Colombia, Bogota.

Villaseñor, P., S. Chávez, and C. Saucedo. 2006. Comportamiento mecánico y fisiológico de frutos de melón (Cucumis melo L.) bajo compresión axial. Rev. Fitotec. Mex. 29(2), 157-162.

Wang, C., J. Pritchard, and C. Thomas. 2006. Investigation of the mechanics of single tomato fruit cells. J. Texture Stud. 37(5), 597-606. Doi: 10.1111/j.1745-4603.2006.00071.x

Wills, R., B. McGlasson, D. Graham, and D. Joyce. 1998. Postharvest: an introduction to the physiology and handling of fruit, vegetables and ornamentals. $2^{\text {nd }} \mathrm{ed}$. CAB International, NewYork, NY.

Yam, J., C. Villaseñor, and E. Romantchik. 2009. Análisis de frutos de guayaba (Psidium guajava L.) bajo compresión y su relación con los procesos fisiológicos. Ing. Agric. Biosist. 1(1), 63-70. Doi: 10.5154/r.inagbi.2009.05.003

Zapata, L., A. Mallaret, and C. Quinteros. 2010. Estudio sobre cambios de la firmeza de bayas de arándanos durante su maduración. Cienc. Docencia Tecnol. (41), 159-71.

Zeebroeck, M., E. Tijskens, J. Dintwa, J. Kafashan, J. Loodts, and H. De Baerdemaeker. 2006. The discrete element method (DEM) to simulate fruit impact damage during transport and handling: Model building and validation of DEM to predict bruise damage of apples. Postharvest Biol. Technol. 41 (2), 85-91. Doi: 10.1016/j. postharvbio.2006.02.007

Zhang, P., R. Whistler, N. James, and B. Bruce. 2005. Hamaker banana starch: production, physicochemical properties, and digestibility. A review. Carbohydr. Polym.59, 443-458. Doi: 10.1016/j.carbpol.2004.10.014

Zulkifli N., N. Hashim, H. Haizi, and M. Firda. 2020. Finite element modeling for fruit stress analysis-Review. Trends Food Sci. Technol. 97, 29-37. Doi: 10.1016/j. tifs.2019.12.029 